4. М. Козюбра. Методологія правознавства і методологія права: співвідношення понять та їх особливості. Право України. 2014. С. 22-32

5. Теремцова Н.В. Основні підходи до розуміння юридичної відповідальності. Європейські перспективи. №1, 2017. С.12-17.

\section{References:}

1. Konstytutsiia Ukrainy: ofits. tekst. Kyiv: KM, 2013. 96 s. [in Ukrainian].

2. Dzeiko Zh. O.(2016). Suchasnyi stan ta priorytetni napriamky rozvytku zakonodavchoi tekhniky $v$ Ukraini: praktychni aspekty [Current state and priority directions of development of legislative technique in Ukraine: practical aspects]. Universytetski naukovi zapysky. - University Science Notes, 3-4, 28-35 [in Ukrainian].
3. O. V. Zaichuk, A. P. Zaiets, V. S. Zhuravskyi, 2008, Teoriia derzhavy prava. Akademichnyi kurs : pidruch. [The theory of state and law] Kiev: Urinkom inter [in Ukrainian].

4. M. Koziubra (2014) Metodolohiia pravoznavstva i metodolohiia prava: spivvidnoshennia poniat ta yikh osoblyvosti. [ Methodology of jurisprudence and methodology of law: correlation of concepts and their featuresn]. - Pravo Ukrainy - Law of Ukraine. [in Ukrainian]

5. Teremtsova N.V. (2017). Osnovni pidkhody do rozuminnia yurydychnoi vidpovidalnosti. [Basic approaches to understanding legal liability.]. Yevropeiski perspektyvy. - European perspective, 1, 12-17 [in Ukrainian].

Received: $28 / 11 / 2019$ 1st Revision: $12 / 12 / 2019$ Accepted: $15 / 01 / 2020$

O. Overchuk, PhD student

Taras Shevchenko National University of Kyiv, Kyiv, Ukraine

\title{
METHODOLOGICAL BASES FOR THE RESEARCH ON THE MECHANISM FOR LAW-MAKING OF A UNITARY STATE
}

The article deals with methodological bases for the of research on the mechanism for of law-making of a unitary state. The article is devoted to the study of the nature and role of methodology in the formation of the Ukraine's legal system during the law-making mechanism. Much attention is given to problematic approaches to determining methodological bases in law-making mechanism. The purpose of this article is to analyze the current state of lawmaking in Ukraine and to make proposals based on the methodology of law. The article explores the concept of methodology on the basis of which the methodological bases of lawmaking are determined. The author states that the methodology of research on lawmaking should cover the analysis of scientific approaches and application of own methods, which allow to identify the most essential characteristics of this legal phenomenon, to distinguish structural elements, to indicate the ways of the most effective preparation and adoption of legal acts. Law-making process is a form of the state activity intended for on the creation (or revision) of legal norms. The law-making process and the role of the legislative bodies in it are based on the constitutional principles of democracy, separation of powers, social state. Scientific search for a theoretical and methodological tool for considering and solving the problems of lawmaking is carried out within the framework of legal positivism - consideration of law as a set of norms established and sanctioned by the state, the violation of which is followed by measures of state coercion. This implies the rejection of the metaphysical side, related to the disclosure of the essence of legal phenomena. The problem of specification as a legal phenomenon is considered. At the heart of the author's research there are the methods used to investigate the elaboration of law-making. The author comes to a conclusion that the choice of a certain method in the course of a specification will promote the improvement of this process as an important legal phenomenon as well as the improvement of modern legislative process.

Keywords: law-making, rulemaking, law-making mechanism, methodology, law-making bodies.

Bulletin of Taras Shevchenko National University of Kyiv Legal Studies, 2019; 4 (111): 39-44

УДК: 347.962 .6

DOI: https:doi.org/10.17721/1728-2195/2019/4.111-8
ISSN 1728-2195

(C) Taras Shevchenko National University of Kyiv Publishing center "Kyiv University", 2019

О. Овчаренко, д-р юрид. наук, доц. Національний юридичний університет імені Ярослава Мудрого, Харків, Україна, Т. Подорожна, д-р юрид. наук, проф. ORCID 0000-0003-0502-950X Торговельно-економічний університет, Львів, Україна

\section{ВІДПОВІДАЛЬНІСТЬ СУДДІ ЗА ПОРУШЕННЯ ПРИПИСІВ КОНВЕНЦІЇ ПРО ЗАХИСТ ПРАВ ЛЮДИНИ ТА ОСНОВОПОЛОЖНИХ СВОБОД}

Досліджено проблеми відповідальності судді за порушення приписів Конвенції про захист прав людини і основоположних свобод. Зазначено, що в теорії права аксіоматичним є твердження, що за неправомірні дії посадових осіб відповідає держава незалежно від їхньої вини. Уповноважені органи держави в таких випадках можуть подати регресний позов у передбаченому законодавством порядку. При цьому спеціальною умовою відповідальності не є скасування незаконного рішення, яким була спричинена майнова шкода. Передумовою майнової відповідальності посадової особи $\epsilon$ ії вина. Зазначено, що майнова відповідальність судді за постановлення незаконних рішень, з огляду на його статус, має певні особливості. По-перше, за міжнародними стандартами, відшкодування суддею майнової шкоди за незаконне судове рішення, яким порушуються права і свободи людини та громадянина, тісно пов'язане з його процесуальною незалежністю й імунітетом. По-друге, установлюється не тільки компенсація державою збитків, що виникли внаслідок неправомірного рішення чи поведінки судді під час виконання його обов'язків, а й право держави на пред'явлення регресних вимог до судді, з вини якого завдано майнову шкоду фізичним або юридичним особам.

Ключові слова: права людини, практика ЄСпЛ, відповідальність судді, процесуальна незалежність судді, відшкодування шкоди, регресні вимоги, вина, професійні обов'язки, незаконне судове рішення.

ВСтУП. Сьогодні досить цікавим видається питання відповідальності держави й суддів як ії̈ представників за порушення зобов'язань, що випливають із Конвенції про захист прав людини і основоположних свобод. У теорії права аксіоматичним є твердження, що за неправомірні дії держави та її посадовців відповідає сама держава незалежно від вини цих посадових осіб, а вже потім вона вправі подати регресний позов у передбаченому законодавством порядку. При цьому спеціальною умовою відповідальності не $є$ скасування незаконного рішення, яким була спричинена майнова шкода. Передумовою майнової відповідальності посадової особи є її вина, на відміну від класичної концепції цивільно-правової відповідальності, що не зумовлена виною її суб'єкта.

Конституційний Суд України у Рішенні від 3 червня 2013 р. № 3-рп/2013 вказав, що "конституційні положення про незалежність суддів $€$ невід'ємним елементом статусу і професійної діяльності останніх і пов'язані з принципом поділу державної влади. Вони зумовлені 
необхідністю забезпечувати підвалини конституційного ладу, прав людини, гарантувати самостійність і незалежність судової гілки влади, що забезпечується, у тому числі, і гарантуванням відповідного фінансування та належних умов для функціонування судів і діяльності суддів, їх правового й соціального захисту" [16].

Специфіка судової влади полягає в особливому порядку фрормування суддівського корпусу і притягнення до відповідальності суб'єктів судової влади - суддів, а також осіб (у виняткових випадках), які беруть участь у судочинстві та права яких гарантовані законодавством [5, с. 11]. Дослідники з країн Західної Європи визнають, що останні зміни і ролі системи правосуддя, і завдань, що перед нею ставляться, служать ключовим чинником у становленні й розвитку інституту відповідальності суддів [23, р. 313]. Указана тенденція відображена у правовій позиції Європейського суду з прав людини (далі - ЄСПЛ, Євросуд), згідно з якою структура системи правового захисту прав людини та основоположних свобод особливо тісно пов'язана з питанням відповідальності суддів, оскільки саме вони є останньою інстанцією цього захисту на національному рівні [20].

Водночас маємо констатувати, що юридична наука, звертаючись до питань правового статусу суддів, здебільшого акцентує увагу на проблемах гарантування їхньої незалежності, опікуючись при цьому встановленням належних гарантій останньої в разі виникнення підстав для притягнення судді до відповідальності [6]. Однак з боку самих представників судової влади обговорювана проблематика викликає занепокоєння і суперечності. Хоча, як вбачається, юридична відповідальність судді, як і відповідальність держави загалом (якщо вона ґрунтується на чітких, прозорих стандартах), не підриває незалежності суду. Навіть навпаки: інститут відповідальності суддів, якщо він функціонує розумно й ефективно, здатен підвищити авторитет системи правосуддя в державі, що $є$ передумовою довіри населення до судової гілки влади й легітимації права загалом [23]. Адже, як зазначають зарубіжні правознавці, належна поведінка суддів - це обов'язкова умова довіри громадян до здійснюваного судочинства, впевненості, що само собою $€$ основною, необхідною передумовою утвердження принципу верховенства права [22]. Поглиблений аналіз майнової відповідальності судді за незаконні або неправосудні рішення, постановлені за його участю, можна знайти у працях вітчизняних вчених (М. Вільгушинський, Л. Виноградова, Л. Москвич, В. Паришкура, С. Подкопаєв, Л. Польовий та ін.). Незважаючи на досить вагомий перелік наукових досліджень проблеми цивільно-правової відповідальності носіїв судової влади, залишається актуальною проблема визначення підстави і передумови такої відповідальності, а також процедурної форми, у якій вона має бути реалізована.

Отже, основною метою нашого дослідження $€$ визначення законодавчо встановленої підстави для відповідальності судді в разі постановлення Європейським судом з прав людини рішення, у якому констатуються порушення прав, передбачених Конвенцією про захист прав людини і основоположних свобод. Поряд із цим мусимо звернути увагу на приводи для такого виду відповідальності та її наслідки.

ВИКЛАД ОСНОВНОГО МАТЕРІАЛУ. МаЙНова відповідальність судді за постановлення незаконних рішень, з огляду на його статус, має свої особливості. Поперше, за міжнародними стандартами, відшкодування суддею майнової шкоди за незаконне судове рішення, яким порушуються права і свободи людини та громадянина, тісно пов'язане з його процесуальною незалежні- стю й імунітетом. По-друге, встановлюється не тільки компенсація державою збитків, що виникли внаслідок неправомірного рішення чи поведінки судді під час виконання своїх обов'язків, а й право держави на пред'явлення регресних вимог до судді, з вини якого завдано майнову шкоду фрізичним або юридичним особам у разі грубого порушення ним правил, які впорядковують виконання ним своїх професійних обов'язків [2; 15].

Як засвідчує детальний аналіз наукової юридичної літератури, сучасні науковці одностайні в тому, що обов'язковою передумовою відшкодування шкоди, завданої суддею при відправленні правосуддя, має бути його умисел на порушення чинного законодавства, унаслідок якого завдано шкоду правам і законним інтересам людини. Вина судді має бути встановлена у спеціальному порядку й зафіксована рішенням уповноваженого органу, зокрема судового [3; 4; 18, с. 22].

Венеційська комісія із цього приводу висловила свої зауваження у відповіді на запитання, чи може суддя нести особисту відповідальність за рішення, винесені на національному рівні, що стали предметом скарги до ЄСПЛ, за наслідками якої було встановлено порушення державою Конвенції про захист прав людини і основоположних свобод (далі - Конвенція), ухвалено дружнє врегулювання або надана одностороння декларація без фактичного встановлення вини національним судом проти цього судді. На думку цього поважного європейського органу, "відповідальність без індивідуальної вини, доведеної судовим вироком, перешкоджає професійній свободі суддів інтерпретувати закон, оцінювати фракти і зважувати докази у справах, як визнано європейськими стандартами. Відповідно до иих стандартів помилкові рішення мають бути оскаржені через апеляційний процес, а не шляхом визнання суддів відповідальними, якщо тільки помилка не $\epsilon$ злим умислом або грубою недбалістю з боку судді. Відповідальність суддів, спричинена негативним рішенням Європейського суду з прав людини, має грунтуватися виключно на висновку національного суду про наявність умислу або грубої недбалості в діях судді. Рішення ЄСПЛ не може використовуватися як єдина підстава для відповідальності судді. Загалом же судді не повинні нести відповідальність за регресним позовом за виконання ними своїх функцій зі здійснення правосуддя згідно з профресійними стандартами, встановленими законом (функціональний імунітет). Виявлення ЄСПЛ порушення Конвенції про захист прав людини і основоположних свобод не обов'язково означає, що судді можуть зазнавати критики на національному рівні за їхні тлумачення й застосування закону (тобто порушення можуть випливати із системних недоліків у державах-членах, наприклад надмірна тривалість провадження, коли особисту відповідальність неможливо встановити" [1].

Законодавство про судоустрій (починаючи з моменту набуття чинності Законом України "Про забезпечення прав на справедливий суд" у 2015 р.) [11] створює передумови для відповідальності судді за порушення Конвенції про захист прав людини і основоположних свобод. Так, згідно з пп. 4 ч. 1 ст. 106 Закону України "Про судоустрій і статус суддів" від 2 червня 2016 р., умисне або у зв'язку з очевидною недбалістю допущення суддею, який брав участь в ухваленні судового рішення, порушення прав людини й основоположних свобод, є підставою для притягнення його до дисциплінарної відповідальності. Оскільки Конвенція передбачає захист саме прав і основоположних свобод людини, то теоретично за цією підставою суддю можна притягти до дисциплінарної відповідальності саме після того, як 
Євросуд визнає порушення Україною ії міжнародноправових зобов'язань. Відповідно до пп. 11 і 12 ст. 109 зазначеного закону дисциплінарне стягнення до судді застосовується не пізніше 3 років від дня вчинення проступку без урахування часу його тимчасової непрацездатності, перебування у відпустці чи здійснення відповідного дисциплінарного провадження. Якщо рішенням ЄСПЛ установлено фракти, які можуть бути підставою для застосування до судді дисциплінарного стягнення, то зазначений термін вираховується від дня набуття таким рішенням Євросуду статусу остаточного. За п. 11 ст. 49 цього ж закону за шкоду, завдану судом, відповідає держава на підставах і в порядку, встановлених законодавством [13].

На підтвердження цієї тези наведемо правові позиції Верховного Суду. Зокрема, в одній із постанов Великої Палати Верховного Суду України йдеться про те, що згідно з ч. 1 та 3 ст. 6 Закону України "Про судоустрій і статус суддів", здійснюючи правосуддя, суди є незалежними від будь-якого незаконного впливу. Суди здійснюють правосуддя на основі Конституції та законів України й на засадах верховенства права. Втручання у здійснення правосуддя, вплив на суд або суддів у будьякий спосіб забороняються і мають наслідком відповідальність, установлену законом.

Щодо цивільної відповідальності, до якої позивач має намір притягнути суд - відповідача, Консультативна рада європейських суддів зазначає, що, беручи до уваги принцип незалежності суду: 1) засобом захисту від судових помилок (стосовно питань юрисдикції, суті справи або процедури розгляду) має бути належна система апеляційного оскарження рішень (як з дозволу суду, так і без дозволу); 2) будь-яка компенсація за інші недоліки в процесі здійснення правосуддя (наприклад порушення термінів розгляду справи) може вимагатися тільки від держави; 3) недоцільним є притягнення судді до будь-якої особистої відповідальності за здійснення ним уповноважених професійних обов'язків, навіть шляхом відшкодування збитків державі, крім випадків навмисного порушення (п. 76 Висновку № 3(2002) Консультативної ради європейських суддів). Крім того, якщо держава повинна була виплатити компенсацію стороні через помилку у відправленні правосуддя, то саме в держави, а не у сторони справи має бути право притягнути суддю до цивільної відповідальності шляхом подання судового позову (п. 37 Висновку № 18(2015) Консультативної ради європейських суддів).

Велика Палата Верховного Суду вважає, що означений підхід однаково застосовний як особисто до суддів, так і до судів, у яких вони здійснюють правосуддя (п. 36 Постанови Великої Палати Верховного Суду від 21 листопада 2018 року у справі № 757/43355/16-ц [8]). У цій же постанові (пп. 61-65) вказано, що можливість розгляду судом позовних вимог про зобов'язання іншого суду вчинити певні процесуальні дії та (або) ухвалити рішення, пов'язане з розглядом іншої судової справи, Закони України не передбачають: "Оскарження діянь суддів (судів) щодо розгляду та розв'язання справ, а також оскарження судових рішень поза порядком, передбаченим процесуальним законом, не допускається. Суди та судді не можуть бути відповідачами у справах про оскарження їхніх дій чи бездіяльності під час розгляду інших судових справ, про оскарження їхніх рішень, ухвалених за наслідками розгляду цих справ, а також про зобов'язання судів та суддів до вчинення певних процесуальних дій. Вчинення (невчинення) суддею (судом) процесуальних дій під час розәляду конкретної справи, а також ухвалені у ній рішення можуть бути оскаржені до суду вищої інстанції у порядку, пе- редбаченому процесуальним законом для тієї справи, під час розгляду якої вони відповідно були вчинені (мали бути вчинені) чи ухвалені" [8].

Оскільки підстави та порядок розподілу судових витрат в адміністративній справі регламентовані процесуальним законом, то звернення позивача з цивільним позовом про стягнення із суду апеляційної інстанції судового збору, нерозподіленого в адміністративній справі судом касаційної інстанції, є необґрунтованим. На це вказує у своїх постановах і Велика Палата Верховного Суду [8; 9].

Отже, якщо держава повинна була виплатити компенсацію стороні через помилку у відправленні правосуддя, то саме в держави, а не у сторони справи має бути право притягнути суддю до цивільної відповідальності шляхом подання судового позову.

У практиці Вищої ради правосуддя на сьогодні вже можна знайти приклади притягнення судді до відповідальності за порушення положень Конвенції про захист прав людини і основоположних свобод, констатованих у рішеннях ЄСПЛ. Наприклад, 5 листопада 2015 р. Вища рада юстиції (із січня 2017 реорганізована у Вищу раду правосуддя) внесла Главі держави подання про звільнення судді Печерського районного суду м. Києва Р. Кірєєва за порушення присяги, в обґрунтування якого покладено рішення ЄСПЛ у справі екс-прем'єрки України Ю. В. Тимошенко. У серпні 2011 р. суддя Р. Кірєєв обрав для Ю. В. Тимошенко запобіжний захід у вигляді тримання під вартою. Своїм рішенням від 30 квітня 2013 р. ЄСПЛ установив порушення Україною своїх зобов'язань за ст. 5 Конвенції з прав людини, визнавши, що тримання під вартою Ю. В. Тимошенко "було свавільним, а обрання запобіжного заходу суддею Р. Кірєєвим учинено без наявного ризику переховування екс-прем'єрки від правосуддя, перешкоджання нею встановлення істини по справі і продовження злочинної діяльності". У січні 2016 Президент України звільнив Р. Кірєєва із займаної ним посади, хоча ще з лютого 2014 він покинув територію України, переховуючись від правосуддя. По суті, це був перший в Україні прецедент відповідальності судді (у вигляді звільнення за порушення присяги) на підставі рішення Європейського суду з прав людини.

Як наголосила член Вищої ради правосуддя А. Лесько, "розгляд питань про відкриття дисциплінарних справ за заявами, які грунтувалися на фракті ухвалення ЄСПЛ рішення щодо України, показав, що порушення Конвениії про захист прав людини і основоположних свобод також випливали із системних недоліків у державі, наприклад через відсутність належного правового регулювання, що саме по собі відзначалося як порушення Конвенції. А у випадках надмірної тривалості судового провадження, у тому числі й унаслідок тривалого невиконання рішення суду, особисту відповідальність судді важко встановити" [14].

Водночас у практиці Вищої ради правосуддя можна знайти досить цікавий прецедент покарання судді, який відступив від практики Європейського суду з прав людини, порушивши тим самим процесуальне законодавство. Суддя Вищого господарського суду України М., виступаючи головою колегії суддів, декілька разів за формальними ознаками (а саме за відсутності документа, який підтверджував би оплату судового збору) повертав касаційну скаргу одного й того самого заявника без розгляду. В основу обґрунтування рішення Вищої ради юстиції від 24 грудня 2015 р. про звільнення судді М. за порушення присяги покладено рішення ЄСПЛ від 25 липня 2002 р. у справі "Совтрансавто-Холдинг проти України", де були схожі фактичні обставини. Євросуд 
констатував, що відхилення Вищого господарського суду України касаційної скарги через несплату заявником судового збору є порушенням права останнього на доступ до правосуддя [17].

Притягти суддю до відповідальності за порушення Конвенції про захист прав людини і основоположних свобод дозволяє й люстраційне законодавство. Наприклад, Закон України "Про відновлення довіри до судової влади в Україні" від 8 квітня 2014 р. передбачає можливість перевірки дій суддів, які одноособово або колегіально ухвалювали рішення з допущенням порушень згаданої Конвенції, констатованих у рішенні ЄСПЛ (ч. 2 ст. 3) [10]. Однією з підстав люстрації за Законом України "Про очищення влади" від 16 вересня 2014 р. було постановлення протиправних рішень, дії чи бездіяльність, які призвели до порушення прав людини й основоположних свобод, визнаних рішенням Євросуду (до осіб, винних у вчиненні таких дій, застосовується заборона протягом п'яти років обіймати свої посади) [12]. Практика застосування згаданих законодавчих приписів засвідчила, що Закон України "Про відновлення довіри до судової влади в Україні" був більш дієвим; кілька десятків суддів, які ухвалювали рішення щодо застосування обмежувальних заходів стосовно учасників протестів кінця 2013 - початку 2014 рр. втратили свої посади. Водночас за Законом України "Про очищення влади" фрактів відповідальності суддів за порушення конвенційних приписів зафіксовано не було.

Як справедливо зазначає С. Б. Поляков, запобігти новим правопорушенням публічної влади можна лише при застосуванні санкцій до особи, винної у вчиненні протиправного діяння [7]. Отже, існує потреба в удосконаленні механізму притягнення судді до цивільноправової відповідальності. Зокрема, треба замислитися над законодавчим закріпленням передумов відшкодування суддею шкоди, присудженої рішенням ЄСПЛ, якщо зафіксоване судом порушення положень Конвенції про захист прав людини і основоположних свобод допущено цим суддею. Компенсація останнім відповідної сатисфракції в порядку регресу повинна мати місце за наявності вини судді в порушенні чинного законодавства, підтвердженої в судовому порядку. Розглядати подібні позови має Верховний Суд України 3 огляду на те, що саме він переглядає справи в разі встановлення міжнародною судовою установою, юрисдикція якої визнана Україною, порушення останньою міжнародних зобов'язань.

Зважаючи на значну кількість звернень українців до ЄСПЛ, варто також розглянути питання відшкодування шкоди особам, щодо яких цей Суд постановив свої рішення. Згідно зі ст. 41 Конвенції про захист прав людини і основоположних свобод, якщо ЄСПЛ визнає факт порушення Конвенції або протоколів до неї і якщо внутрішнє право відповідної Високої Договірної Сторони передбачає лише часткове відшкодування, то Суд у разі необхідності надає потерпілій стороні справедливу сатисфакцію. Виплата сатисфакції, як і виконання рішення Євросуду, - безумовний обов'язок держави. Закон України "Про виконання рішень та застосування практики Європейського суду з прав людини" передбачає, що виплата справедливої сатисфракції, призначеної ЄСПЛ, здійснюється через Державний бюджет країни. А вже Міністерство юстиції України вправі звернутися 3 позовом про відшкодування збитків, завданих Державному бюджету України, до особи, з вини якої Європейським судом було прийнято рішення проти України. Інакше кажучи, збитки, завдані Державному бюджету України, мають стягуватися 3 державних службовців, 3 вини яких ЄСПЛ ухвалив рішення проти України. Відповідно до звітів Урядового уповноваженого у справах Європейського суду з прав людини статистика стягнення коштів з Державного бюджету України на користь заявників у зв'язку з порушенням нею Конвенції про захист прав людини і основоположних свобод за останні кілька років виглядає так: у 2013 р. ЄСПЛ зобов'язав Україну сплатити справедливих компенсацій на суму 46551198,67 євро, у 2014 - 46738812,53 , у 2015 527146,6 , у 2016 - понад 300000000 [19], у 2018 1018 425,14 євро [21]. Як бачимо, суми збитків, що завдаються неправомірними діяннями органів державної влади та їхніх посадових осіб українським громадянам, $€$ значними. Водночас аналіз судової практики дає підстави стверджувати, що зазвичай Міністерство юстиції не пред'являє позовів до посадовців України про відшкодування збитків, завданих Державному бюджету України. Спроби громадських активістів отримати інфрормацію в Міністерстві з указаного питання зазвичай безуспішні. Можна припустити, що це зумовлено політичними аспектами, а саме небажанням Міністерства юстиції (з невідомих причин) займатися такими справами.

Ще один кейс, який не є типовим, але доволі важливий для України. У цьому кейсі суддя отримав покарання за допущені порушення, які через десять років були визнані Європейським судом з прав людини правомірними. 29 липня 2011 р. до Ужгородського міськрайонного суду Закарпатської області звернувся представник компанії "Марег Естейтс Лімітед" ОСОБА 1 з позовною заявою до ОСОБА_2, третя особа - ТОВ "ІмперіалСіті", про зобов'язання вчинити дії з підписання та нотаріального посвідчення установчих документів і визнання позивача учасником ТОВ "Імперіал-Сіті". Також позивач просив визнати наявність у вказаного товариства права до 25 червня 2012 р. здійснювати підприємницьку діяльність з організації та проведення азартних ігор. Провадження у вказаній справі відкрито постановленою під головуванням судді Сочки В. І. ухвалою суду від 9 серпня 2011 р. Заочним рішенням суду від 12 серпня 2011 р. заявлені позовні вимоги задоволено повністю. Зокрема, визнано наявність у ТОВ "ІмперіалСіті" права в термін до 25 червня 2012 р. здійснювати підприємницьку діяльність 3 організації діяльності 3 проведення азартних ігор (діяльності з організації та проведення азартних ігор у казино), яке надано йому на підставі ліцензії Міністерства фрінансів України серії AB № 433993 від 2 грудня 2008 р., та ліцензії Полтавської обласної державної адміністрації серії АВ № 419708 від 17 грудня 2008 р. на організацію та утримання тоталізаторів, гральних закладів у зв'язку з нерозповсюдженням на ТОВ "Імперіал-Сіті" дії Закону України "Про заборону грального бізнесу в Україні". Прийняття такого рішення суддя Сочка В. І. мотивував, зокрема, тим, що "...позивач, прийнявши рішення про вкладення власних майнових цінностей в об'єкт інвестування ТОВ "Імперіал-Сіті", згідно з положеннями ст. 5 Закону України "Про інвестиційну діяльність" $€$ інвестором, права якого в даному випадку також протиправно порушені неправомірною бездіяльністю відповідача". У рішенні згадано, що Законом України від 10 листопада 1994 р. ратифіковано Угоду про партнерство і співробітництво між Україною і Європейськими Співтовариствами та їх державами-членами, яка набрала чинності 1 березня 1998 р. (далі - Угода). 15 травня 2009 р. Верховна Рада України прийняла Закон "Про заборону грального бізнесу в Україні", який набув чинності 25 червня 2009 р. Суд у мотивувальній частині заочного рішення, серед іншого, послався на ст. 19 Закону України "Про міжнародні до- 
говори України", якою визначено, що чинні міжнародні договори України, згода на обов'язковість яких надана Верховною Радою України, є частиною національного законодавства і застосовуються у порядку, передбаченому для норм національного законодавства. Якщо міжнародним договором України, який набув чинності в установленому порядку, встановлено інші правила, ніж ті, що передбачені у відповідному акті законодавства України, то застосовуються правила міжнародного договору. Згідно з п. 4 ст. 36 Угоди "якщо нове законодавство чи правила, які запроваджено в Україні, можуть спричинити більш обмежені умови для заснування компаній Співтовариства на її території і для функціонування дочірніх компаній і фріліалів компаній Співтовариства, заснованих в Україні, ніж ті, що склалися на день підписання Угоди, то такі відповідні законодавство чи правила не застосовуються протягом трьох років після набуття чинності відповідним законом до тих дочірніх компаній і філіалів, які вже були створені в Україні на момент набуття чинності відповідним актом. Республіка Кіпр є членом Європейського Союзу з 1 травня 2004 року".

3 огляду на викладене, суддя Сочка В.І. дійшов висновку: оскільки на час ратифікації Україною Угоди заборони на гральний бізнес та азартні ігри ще не було, то дія Закону України "Про заборону грального бізнесу в Україні" не може поширюватись на ТОВ "Імперіал-Сіті" протягом трьох років, тобто до 25 червня 2012 р. включно.

У січні 2012 р. Вища рада юстиції розпочала дисциплінарне провадження щодо судді Сочки В. І. на підставі скарги, яка надійшла щодо його дій. Вища рада юстиції встановила, що частина позовних вимог компанії "Марег Естейтс Лімітед" підлягала розгляду в порядку господарського судочинства, суддя Сочка В. І., згідно з вимогами п. 1 ч. 2 ст. 122 ЦПК України, був зобов'язаний ще на стадії прийняття позову відмовити у відкритті провадження або, у разі помилкового відкриття провадження, відповідно до п. 1 ч. 1 ст. 205 ЦПК України, прийняти рішення про його закриття. 29 січня 2013 р. Вища рада юстиції внесла подання Президентові України про звільнення судді Сочки В. І. за порушення присяги.

27 червня 2019 р. Європейський суд з прав людини ухвалив рішення у справі "Svit Rozvag, TOV and others v. Ukraine". Справа стосувалася заборони на азартні ігри, запровадженої в Україні 2009 року. Суд визнав порушення Україною права власності й присудив 300000 євро ТОВ "Світ Розваг", 58500 євро - пані Станко і 135000 євро - ПП "Ігро-Бет" на відшкодування матеріальної шкоди, і 17000 євро - ТОВ "Світ Розваг", 2200 євро - пані Станко і 214 євро - ПП "Ігро-Бет" стосовно судових витрат. У прецедентному праві Суду встановлено, що припинення дії ліцензій на бізнес $€$ втручанням у право на мирне володіння майном, гарантоване ст. 1 Протоколу № 1 до Конвенції з прав людини. Суд врахував ті факти, що заявники не порушували норм законодавства, перехідний період набуття чинності закону, що забороняв ігровий бізнес, тривав всього 40 днів 3 моменту прийняття законодавчих змін про заборону ігрового бізнесу до вступу внаслідок, що було необґрунтовано мало, а також не було передбачено будь-якої компенсації у зв'язку з анулюванням ліцензій заявників, які були в законний спосіб отримані відповідно до чинного на той момент законодавства. Заявники подавали позови про компенсацію шкоди, які були повністю відхилені національними судами. Тож міра, застосована до заявників, була пропорційною, переважно через якість процесу ухвалення рішень. 3 огляду на всі обставини, ЄСПЛ констатував порушення статті Конве- нційних гарантій і зобов'язав Україну виплатити власникам ігрових салонів компенсацію. По суті, Європейський суд з прав людини визнав порушення Україною своїх зобов'язань, підтвердивши законність дій екс-судді Сочки В. І., якого було звільнено з посади. Механізму перегляду рішення про звільнення судді Сочки В. І. немає, оскільки відповідно до процесуального закону перегляд рішення суду за виключними обставинами (ч. 3 ст. 323 , п. 3 ч. 1 ст. 324 ЦПК) відбувається тільки за скаргою осіб, які брали участь у цій справі. Необхідною передумовою такого перегляду рішення Верховним Судом є факт визнання порушення Україною своїх зобов'язань у Європейському суді з прав людини виключно стосовно відповідного заявника. Особи, які постраждали від аналогічних порушень на національному рівні, не можуть застосувати рішення Страсбурзького суду, постановлене не за їхньою справою, для звернення до Верховного Суду, а мають самостійно звертатися до ЄСПЛ. Безумовно, це є недоліком вітчизняного процесуального законодавства.

ВИсновкИ. Отже, чинне законодавство України створює передумови для притягнення судді до дисциплінарної й цивільно-правової відповідальності в разі постановлення Європейським судом з прав людини рішення, у якому констатуються порушення прав, передбачених Конвенцією про захист прав людини і основоположних свобод. Формування реальної практики притягнення винних посадових осіб судової влади до цих видів відповідальності стане важливим кроком для впровадження демократії в Україні, утвердження справедливості й режиму верховенства права. Водночас відповідальність судді за порушення прав та основоположних свобод людини має бути обмежена випадками, коли такі факти доведені через установлені законом процедури (насамперед ідеться про дисциплінарну відповідальність судді). Одним із приписів міжнародних стандартів незалежності суддів $€$ вимога, відповідно до якої тільки держава може відповідати за судові помилки. Вона ж може домагатись і цивільно-правової відповідальності судді в установленому законодавством порядку, якщо доведено, що шкоду було завдано під час виконання ним обов'язку з відправлення правосуддя за наявності його вини в порушенні закону або посадових обов'язків.

Список використаних джерел:

1. ВК висловилась щодо відповідальності судді за свої рішення. Закон і Бізнес. 2016. 17 черв. URL: http://zib.com.ua/ua/124250venecianska_komisiya_vislovilas_schodo_vidpovidalnosti_suddi.html (дата звернення: 05.12.2019).

2. Організація роботи суду в Україні: навч. посіб. / за заг. ред. І. Є. Марочкіна. Харків: Нац. юрид. акад. України, 2009. 312 c. (in Ukrainian).

3. Ответственность в управлении: учебник / И.Л.Бачило, Х. Я. Калла и др.; отв. ред. Б. М. Лазарев и А. Е. Лунев. Москва: Наука, 1985. 303 c.

4. Подкопаєв С. В. Про підставу дисциплінарної відповідальності суддів. Юрид. вісн. 2005. № 12. С. 119-121.

5. Поздняков М. Критерии оценки качества работы судей и дисциплинарная ответственность: монография. Санкт-Петербург: НИИ центр "Ин-т проблем правоприменения", 2014. 70 с.

6. Польовий О. Л. Гарантії суддівської незалежності при притягненні суддів до юридичної відповідальності: автореф. дис. ... канд. юрид. наук: 12.00.10. Київ, 2014. 20 с.

7. Поляков С. Б. Правонарушитель - орган судебной власти? Рос. судья. 2010. № 9. С. 26-30.

8. Постанова Великої Палати Верховного Суду України від 21.11.2018 у справі № 757/43355/16-ц. Єдиний державний реєстр судових рішень. URL: http://reyestr.court.gov.ua/Review/78977475 (дата звернення: 05.12.2019)

9. Постанова Великої Палати Верховного Суду України від 29.05.2019 у справі № 489/5045/18-ц. Єдиний державний реєстр судових рішень. URL: http://reyestr.court.gov.ua/Review/82885634 (дата звернення: 05.12.2019).

10. Про відновлення довіри до судової влади в Україні: Закон України від 08.04.2014 № 1188-VII. Офріц. вісн. України. 2014. № 31. 
11. Про забезпечення права на справедливий суд: Закон України від 12.02.2015 № 192-VIII. Офріи. вісн. України. 2015. 10 берез. № 17. Ст. 447.

12. Про очищення влади: Закон України від 16.09.2014 № 1682-VII. Офріц. вісн. України. 2014. № 82. Ст. 2317.

13. Про судоустрій і статус суддів: Закон України від 02.06.2016 № 1402-VIII. Офріu. вісн. України. 2016. № 56. Ст. 1935.

14. Проблема виконання рішень Європейського суду з прав людини: необхідність системного аналізу та впровадження. Вища рада правосуддя: офріu. сайт. 2016. 23 листоп. URL: http://www.vru.gov.ua/news/ 1880 (дата звернення: 05.12.2019)

15. Рекомендація CM/Rec(2010)12 Комітету Міністрів Ради Європи державам-членам щодо суддів: незалежність, ефективність та обов'язки від 17.11.2010. База даних "Законодавство України" / BP України. URL: http://zakon.rada.gov.ua/cgi-bin/laws/main.cgi?nreg= 994_а38 (дата звернення: 05.12.2019).

16. Рішення Конституційного Суду України у справі за конституційним поданням Верховного Суду України щодо відповідності Конституції України (конституційності) окремих положень ст. 2, абз. 2 п. 2 розд. II "Прикінцеві та перехідні положення" Закону України "Про заходи щодо законодавчого забезпечення реформування пенсійної системи", статті 138 Закону України "Про судоустрій і статус суддів" (справа щодо змін умов виплати пенсій і щомісячного довічного грошового утримання суддів у відставці) від 03.06.2013 № 3рп/2013. Офріц. вісн. України. 2013. № 44. Ст. 1583

17. Совтрансавто-Холдинг проти України: рішення Європейського суду з прав людини від 25.07.2002. База даних "Законодавство України" / ВP України. URL: http://zakon0.rada.gov.ua/laws/show/980_043 (дата звернення: 05.12.2019)

18. Тиганов А. И. Юридическая ответственность судей в Российской империи во второй половине XIX - начале XX вв. История государства и права. 2010. № 22. С. 19-24.

19. Урядовий уповноважений у справах Європейського суду з прав Міністерство юстиції України: офіц. вебсайт. URL: http://old.minjust.gov.ua/8030 (дата звернення: 05.12.2019).

20. Цирфа Ю. Правосуддя як утвердження загальнолюдської справедливості. Віче. 2011. № 19. URL: http://www.viche.info/journal/ 2738/ (дата звернення: 05.12.2019).

21. Щорічний звіт про результати діяльності Уповноваженого у справах Європейського суду з прав людини у 2018 році. Головне територіальне управління юстииії в Тернопільській області: офріц. сайт. URL: http://terjust.gov.ua/wp-content/uploads/2016/05/\%D0\%B7\%D0\%B2\% D1\%96\%D1\%82-2018.pdf (дата звернення: 05.12.2019).

22. Neubauer D. W., Meinhold S. S. Judicial Process: Law, Courts, and Politicsin the United States. 5 ed. Wadsworth Publish., 2009. 576 p.

23. Terhechte J. Ph. Judicial Accountability and Public Liability. The German "Judges Privilege" Under the Influence of European and International Law. German Law Journal. 2012. Vol. 13. P. 313-330.

\section{References:}

1. VK vyslovylas shchodo vidpovidalnosti suddi za svoi rishennia [The EC expressed its responsibility for the judge's decisions]. Zakon i Biznes. 2016. 17 cherv. (in Ukrainian).

2. Orhanizatsiia roboty sudu $v$ Ukraini [Organization of the court in Ukraine]: navch. posib. I za zah. red. I. Ye. Marochkina. Kharkiv: Nats. yuryd. akad. Ukrainy, 2009. 312 s. . (in Ukrainian).

3. Otvetstvennost' $v$ upravlenii [Responsibility in management] uchebnik / I. L. Bachilo, H. Ja. Kalla i dr.; otv. red. B. M. Lazarev i A. E. Lunev. Moskva: Nauka, 1985. 303 c. (in Russian)

4. Podkopaiev S. V. Pro pidstavu dystsyplinarnoi vidpovidalnosti suddiv [About the discipline of the disciplinary court of judiciary]. Yuryd. visn. 2005. № 12. S. 119-121. . (in Ukrainian).

5. Pozdnjakov M. Kriterii ocenki kachestva raboty sudej disciplinarnaja otvetstvennost' [Judicial Performance Criteria and Discipli- nary Responsibility]: monografija. Sankt-Peterburg: NII centr "In-t problem ravoprimenenija", 2014. 70 s. (in Russian).

6. Polovyi O. L. Harantii suddivskoi nezalezhnosti pry prytiahnenni suddiv do yurydychnoi vidpovidalnosti [Guarantees of judicial independence in bringing judges to justice]: avtoref. dys. ... kand. yuryd. nauk: 12.00.10. Kyiv, 2014. 20 s. (in Ukrainian).

7. Poljakov S. B. Pravonarushitel' - organ sudebnoj vlasti? [Is the offender a judicial authority?] Ros. sud'ja. 2010. № 9. S. 26-30. (in Russian)

8. Postanova Velykoi Palaty Verkhovnoho Sudu Ukrainy vid 21.11.2018 u spravi №757/43355/16-ts. Yedynyi derzhavnyi reiestr sudovykh rishen. (in Ukrainian).

9. Postanova Velykoi Palaty Verkhovnoho Sudu Ukrainy vid 29.05.2019 u spravi № 489/5045/18-ts. Yedynyi derzhavnyi reiestr sudovykh rishen. (in Ukrainian).

10. Pro vidnovlennia doviry do sudovoi vlady v Ukraini: Zakon Ukrainy vid 08.04.2014 № 1188-VII. Ofits. visn. Ukrainy. 2014. № 31. (in Ukrainian).

11. Pro zabezpechennia prava na spravedlyvyi sud: Zakon Ukrainy vid 12.02.2015 № 192-VIII. Ofits. visn. Ukrainy. 2015. 10 berez. № 17. St. 447. (in Ukrainian).

12. Pro ochyshchennia vlady: Zakon Ukrainy vid 16.09.2014 № 1682VII. Ofits. visn. Ukrainy. 2014. № 82. St. 2317. (in Ukrainian).

13. Pro sudoustrii i status suddiv: Zakon Ukrainy vid 02.06.2016 № 1402-VIII. Ofits. visn. Ukrainy. 2016. № 56. St. 1935. (in Ukrainian)

14. Problema vykonannia rishen Yevropeiskoho sudu $z$ prav liudyny: neobkhidnist systemnoho analizu ta vprovadzhennia. Vyshcha rada pravosuddia: ofits. sait. 2016. 23 lystop. (in Ukrainian).

15. Rekomendatsiia CM/Rec(2010)12 Komitetu Ministriv Rady Yevropy derzhavam-chlenam shchodo suddiv: nezalezhnist, efektyvnist ta obov'iazky vid 17.11.2010. Baza danykh "Zakonodavstvo Ukrainy" / VR Ukrainy. (in Ukrainian).

16. Rishennia Konstytutsiinoho Sudu Ukrainy u spravi za konstytutsiinym podanniam Verkhovnoho Sudu Ukrainy shchodo vidpovidnosti Konstytutsii Ukrainy (konstytutsiinosti) okremykh polozhen st. 2, abz. 2 p. 2 rozd. II "Prykintsevi ta perekhidni polozhennia" Zakonu Ukrainy "Pro zakhody shchodo zakonodavchoho zabezpechennia reformuvannia pensiinoi systemy", statti 138 Zakonu Ukrainy "Pro sudoustrii i status suddiv" (sprava shchodo zmin umov vyplaty pensii i shchomisiachnoho dovichnoho hroshovoho utrymannia suddiv u vidstavtsi) vid 03.06.2013 № 3rp/2013. Ofits. visn. Ukrainy. 2013. № 44. St. 1583. (in Ukrainian)

17. Sovtransavto-Kholdynh proty Ukrainy: rishennia Yevropeiskoho sudu z prav liudyny vid 25.07.2002. Baza danykh "Zakonodavstvo Ukrainy" / VR Ukrainy. (in Ukrainian).

18. Tiganov A. I. Juridicheskaja otvetstvennost' sudej $v$ Rossijskoj imperii vo vtoroj polovine XIX - nachale XX v. [Legal responsibility of judges in the Russian Empire in the second half of the 19th - beginning of the 20th centuries] Istorija gosudarstva i prava. 2010. № 22. S. 19-24. (in Russian).

19. Uriadovyi upovnovazhenyi u spravakh Yevropeiskoho sudu z prav liudyny. Ministerstvo yustytsii Ukrainy: ofits. vebsait. (in Ukrainian)

20. Tsyrfa Yu. Pravosuddia yak utverdzhennia zahalnoliudskoi spravedlyvosti [Justice as an affirmation of universal justice]. Viche. 2011. № 19. (in Ukrainian).

21. Shchorichnyi zvit pro rezultaty diialnosti Upovnovazhenoho $u$ spravakh Yevropeiskoho sudu z prav liudyny u 2018 rotsi [Annual Report on the Performance of the Commissioner for European Court of Human Rights in 2018]. Holovne terytorialne upravlinnia yustytsii $v$ Ternopilskii oblasti: ofits. sait. (in Ukrainian)

22. Neubauer D. W., Meinhold S. S. Judicial Process: Law, Courts, and Politicsin the United States. 5 ed. Wadsworth Publish., 2009. 576 p. (in English)

23. Terhechte J.Ph. Judicial Accountability and Public Liability. The German "Judges Privilege" Under the Influence of European and International Law. German Law Journal. 2012. Vol. 13. P. 313-330. (in English).

Received: $06 / 12 / 2019$ Accepted: $15 / 01 / 2020$

O. Ovcharenko, PhD (Law), Associate prof.

Yaroslaw Mudriy National Law University, Kharkiv, Ukraine,

T. Podorozna, PhD (Law), Associate prof.

Legal Faculty of Lviv University of Trade and Economics, Lviv, Ukraine

\section{JUDGES' LIABILITY FOR VIOLATION OF CONVENTION FOR THE PROTECTION OF HUMAN RIGHTS AND FUNDAMENTAL FREEDOMS}

The article focuses on the judge's liability vilotaion of the Convention for the Protection of Human Rights and Fundamental Freedoms. State officials' wrongful acts result in liability of a state regardless of the fault of those officials are determined as axiomatic for the theory of law. The state agencies, where the officials are employed, are entitled to file regress suits in accordance with the procedure provided by law. In such a case, cancellation or annulment of the wrongful act that causes damages, should not be regarded as a special precondition for the liability of the state official liable for committing such an act. The precondition of the liability of the official should be his or her fault. It is essential that the liability of a judge for issuing wrongful judicial acts, regarding his or her status, has its own peculiarities. First, according to international standards, liability of a judge for delivering an illegal judgment, that had causes financial damage and interfereance with personal rights and freedoms, is predetermined by his or her procedural independence and immunity. Secondly, compensation for losses incurred by the state as a result of a wrongful decision or conduct of a judge in the performance of his / her duties is established. In addition to this, the state has the right to bring regress suits against a judge who has caused such damages to individuals or legal entities.

Keywords: human rights, ECHR practice, judge's liability, procedural independence, reparation, regress suits, guilt, professional duties, an unlawful judgment. 